\title{
The New Aspects of the Economic Relations between European Union and China
}

\author{
Zdzisław W. Puślecki \\ Chair of Department of International Economics \\ Adam Mickiewicz University, Poznań, \\ Ul. Umultowska 89 A. 61-614 Poznań, Poland
}

\begin{abstract}
In this research work, Author focus on the analysis of the new aspects of the economic relations between European Union and People Republic China. What indicates the importance and innovativeness of the research is the presentation of the technical progress especially in China, the growth of economic ties with the European Union and the benefits resulting from liberalised of the China foreign trade policy under WTO. Accordance to the foreign trade policy theory further trade liberalisation and improved framework policies would increase trade and promote growth. In the new circumstances for the development of the global economy and the global trade, People Republic of China seems to be a production superpower, able to change the world trade and also the European Union's extra trade. In many areas it possesses comparative advantages. China may continue their development to specialise in electronics and increasingly in services. With or without further trade agreements between two partners, services will be more traded and trade policies will have to adjust to changes in the organisation of global value change. With new investments, a country can transform its position through industrial expansion at home and sustain it through international trade. China is especially sensitive to the advantages of intensive growth and will not wish to disrupt essential economic arrangements that have been crucial to her success. The main aim of the article is the presentation of the new aspects of the economic relations between European Union and China.
\end{abstract}

Key words: inequality development, foreign trade, liberalisation effects, intensive economic growth, Europe 2020, Horizon.

\section{INTRODUCTION}

It must be emphasized that there are the need for new approaches to trade cooperation in light of the forces that are currently re-shaping international business. It suggests that the multilateral trading system will need to adjust to developments in trade and in the trading environment. The key of trade developments within the broader socio-economic context is especially the rise of global supply chains, the general shift of trade power away from the West towards Asia and especially to China. A long-termed stability of China depends however on the fast economic growth, which is possible only when this country will be a partner able to play global roles. Question raised is whether the West will see China's rise as an opportunity for cooperation or for conflict. In the research were used quantity and quality methodology the main aim of the article is the presentation of the new aspects of the economic relations between European Union and China. In the article presents the economic progress and inequality development of China, the liberalisation effect of China foreign trade policy under 
World Trade Organisation (WTO), the increase of China role in the European Union extra trade, European Union and China in the light of global competitiveness strategy of Europe 2020.

\section{INTENSIVE ECONOMIC GROWTH AND INEQUALITY DEVELOPMENT OF CHINA}

The path of convergence depends on a host of factors: technology, skilled labor, foreign direct investment (FDI), resource endowment, government restrictions and so forth. Generally, convergence is faster and more effective in regional sectors that are linked by open trade and fact or mobility (Jian, Sachs and Warner, 1996). Many of the forces of convergence are repressed in socialist economies. In China, restrictions imposed on the movement of labor and favoritism shown to state owned enterprise (SOE) reduces the self-correcting forces of free markets. Constraints against unregistered migration from rural to urban areas are not currently as restricted as they were before 1980. Still unregistered migrants may lack access for their children to schools and medical services (Doherty and Lu, 2013).

There is a huge difference in the economic well being of urban versus rural and coastal versus inland residents. Substantial income growth occurred in eastern, southern and northeastern China. Very little development occurred beyond Chongqing into central China or further west. Since 2000, eight provinces accounting for $40 \%$ of the population have generated $75 \%$ of the growth in GDP. In 2006, Shanghai had a per capita income of $\$ 15,000$ while Guizhou's per capita income was a mere $\$ 1,247$ on a purchasing power parity basis (Reuvid, 2008: 55).

The Solow-Swan growth model demonstrates that regional (and country) differences in per capita income are largely the result of differences in the capital-labor ratio (K/L). Higher K/L ratios produce higher growth rates in per capita income over regions and the opposite is true for lower ratios. Given factor mobility, labor will migrate to capital rich regions and capital will move to labor rich regions. Factor mobility across sectors will speed the rate of convergence. Studies have shown that this convergence pattern has occurred among the states of the US and the countries comprising the Common Market (Sachs and Warner, 1995) like in the European Union.

China is divided into 30 provinces. These provinces can be aggregated into three regions: North Coastal, South Coastal, and Interior. The North Coastal Provinces (Including Shanghai, Tianjin, and Liaoning) have the highest income levels. The South Coastal regions (e.g., Guangdong, Fujian and Zhejiang) are next. The Interior provinces (e.g., Shaanxi, Shanxi and Ningxia) have considerably less income (Jian ET al.1996)

In 2002, the 16th NCCPC (National Congress of Communist Party of China) established policies to raise the income of farmers and improve the efficiency of agriculture. Over the next several years the CPCCC (Communist Party China Central Committee) introduced initiatives to:

1. give priority and provide greater assistance to less developed areas;

2. expand employment opportunities and enhance public services such as, education and medical care;

3. reform onerous rural farm taxes; the overall burden on farmers was reduced from $8.4 \%$ to 6\% (Chen, 2009:125);

4. provide a substantial agricultural subsidy program for farmers which was introduced in 2004; by 2008, farmers received RMB 1 to billion;

5. Make significant increases in rural basin infrastructure, e.g., electric, utilities, highways, and water and biogas utilities.

In 2006, the rural residence population was 949 million. About 230 million of rural laborers were working in urban areas (Chen, 2009: 134). China's farms are much too small to operate 
efficiently. Combining farms, farming cooperatives will release millions of laborers. How to employ the released labor is a long term and monumental problem that must be solved by the government.

To presents the spectacular growth and inequality in China important is the following equation and its major component parts:

$\mathrm{Y}=\mathrm{C}+\mathrm{I}+\mathrm{G}+$ Exports - Imports $(1)$

Where $\mathrm{Y}=$ Gross Domestic Products (GDP or Income)

$\mathrm{C}=$ Consumption

$\mathrm{I}=$ Investment (Domestic and Foreign)

$\mathrm{G}=$ Government Expenditures

China's growth was largely fueled by government expenditure in heavy investment, infrastructure, resource development and residential and commercial real estate. In the 1980's consumer spending exceeded 50 percent of GDP. However, by 2009, consumer expenditure dropped to $30 \%$ of GDP as government spending for infrastructure and the export industries overwhelmed residential consumption. In the most recent five-year plan, nonfarm workers are scheduled to receive wage increases of up to 15 percent annually for the next five years. This is projected to increase consumer spending to 45 percent of GDP. This would represent an increase in consumer spending of $\$ 540$ billion. In terms of Eq. (1), consumption (C) will play a greater role in the growth of GDP and this will produce a more balanced and sustainablegrowth path (Doherty and Lu, 2013).

The current 11th Five Year Plan recognizes the following imbalances in past growth strategies:

1. heavy reliance on investment and efforts at the expense of domestic demand;

2. emphasis on heavy industry over services;

3. increases in income disparity between urban and rural areas and between inland and coastal provinces; and

4. Large differences in access to social, medical and educational services (Doherty and Lu, 2013).

The global crisis of 2008-2009 affected China's economy via exports, foreign domestic investment (FDI) links and the real estate market; China adopted a huge stimulus plan to counter the depression effect of the international crisis. As a result, China's economy grew 8.7\% in 2009 (World Bank China (2009), Research Working Paper No. 9). China's GDP growth for 2011 is forecasted to be 9.1 to $10.0 \%$, according to Goldman Sach's Global Economics, Commodities and Strategy (ECS) Research group (Sachs, 2010). China's GDP growth for 2012 is forecasted to be $9.5 \%$ ( Sachs, 2010). Between 2010 - 2020, China's average annual real GDP growth rate is expected to be 9.5\% (Top 10 largest economies..., 2010). In a 2011 Gallup poll, $52 \%$ of Americans named China as the world's leading economic power today compared to only $32 \%$

Of Americans naming their own country (China Surges in Americans' Views.....2011). The stimulus was composed of infrastructure spending, tax cuts, consumer subsidies, and transfer payments. Also, substantial loans to local governments were made for infrastructure projects. The share of total new lending going to residents; e.g., mortgages, increased from $14 \%$ in 2008 to $26 \%$ in 2009. Policy makers stress that future growth should be driven more by consumption and that the benefits of prosperity should be more evenly shared. There needs to 
be a reallocation of resources to sectors that have been shortchanged or ignored. Financial sector

Table 1 Real GDP Growth Forecasts

\section{Real GDP Growth Forecasts}

\begin{tabular}{|l|c|c|c|c|c|c|}
\hline \multirow{2}{*}{ \% yoy } & \multirow{2}{*}{2009} & \multicolumn{2}{|c|}{2010} & \multicolumn{2}{c|}{2011} & \multirow{2}{*}{\begin{tabular}{c} 
2012 \\
\cline { 3 - 6 }
\end{tabular}} \\
\cline { 3 - 6 } & & CS & Consensus & GS & Consensus* & (CS) \\
\hline USA & -2.6 & 2.8 & 2.7 & 2.7 & 2.4 & 3.6 \\
Japan & -5.2 & 3.5 & 3.0 & 1.1 & 1.2 & 2.0 \\
Euroland & -4.0 & 1.7 & 1.6 & 2.0 & 1.4 & 1.9 \\
UK & -5.0 & 1.8 & 1.7 & 2.4 & 2.0 & 2.6 \\
Brazil & -0.2 & 7.5 & 7.6 & 5.0 & 4.5 & 4.3 \\
China & 9.1 & 10.1 & 10.1 & 10.0 & 9.1 & 9.5 \\
India & 7.4 & 8.5 & 8.4 & 8.7 & 8.5 & 8.3 \\
Russia & -7.9 & 3.8 & 4.0 & 5.3 & 4.3 & 5.6 \\
\hline BRICs & 5.5 & 8.7 & 8.6 & 8.6 & 7.9 & 8.2 \\
Advanced & -3.2 & 2.9 & 2.8 & 2.5 & 2.2 & 3.0 \\
Economies & & & & & & \\
World & -0.6 & 4.9 & 4.7 & 4.6 & 4.1 & 4.8 \\
\hline
\end{tabular}

* Consensus Economics November 2010

Source: GS Global ECS Research

Source: Goldman Sachs Global ECS Research, Dec. 2010

Chart 1 Perceptions of the World's Leading Economic Power Today

Perceptions of World's Leading Economic Power Today

Which one of the following do you think is the leading economic power in the world

today -- [the United States, the European Union, Russia, China, Japan, India]?

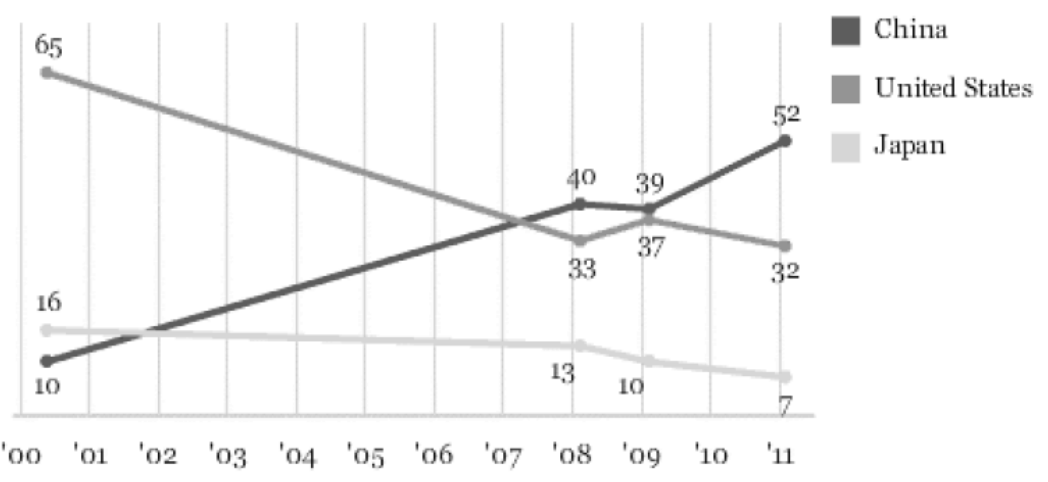

GALLUP

Source: Gallup's annual World Affairs survey, "China Surges in Americans' Views of Top World Economy" Feb. 2011 
Reform is needed to improve access to funds by private enterprises, particularly service firms and small-size firms. In addition to financial reforms, adjustments are needed in prices and taxes to eliminate the subsidization of industrial (capital) inputs. Also, the dividend policy of state-owned-enterprise (SOEs) must be revised to achieve a more efficient allocation of investment funds. Finally, restrictions of private firms to enter the service sector should be revised (Doherty and $\mathrm{Lu}, 2013$ ).

\section{THE LIBERALISATION EFFECT OF CHINA FOREIGN TRADE POLICY UNDER WTO}

The access of PRChina to the World Trade Organisation (WTO) (November 2001) was the moment in which new trade rules became obligatory. The WTO - through its agreements on safeguards and antidumping, offer some recourse for states to rein in the forces of free trade. However, many experts suggest that there are legal ambiguities in WTO regime that have limited invocation of safeguard measures, (Kawase, 2006). Japan is moving toward the use of WTO-consistent safeguards. These concerns have been fueled because there is increasing Chinese competition in week industries and because it is harder to request supplying countries to take grey measures such as VERA in agriculture and textiles than it was in the past (e.g., edible fats from New Zealand; textiles from Korea and China). But officials do not appear to have high hopes of using safeguards as a matter of routine under the WTO because the text and precedents regarding the Safeguard Agreement are murky enough to deter successful invocation and because, if it takes place, invocation is scrutinized heavily in the WTO disputesettlement system (Kawase, 2005), (Kawase, 2006). In the next five years after the acces to the WTO China eliminated all kinds of quotas and other non-tariff barriers that slow down the inflow of foreign goods. Customs duties which were lowered were gradually reduced to an average of $9 \%$. Foreign banks received the right to introduce the foreign ownership in 100\% of economic

China is now the biggest exporter and receiver of foreign investments. China is the world's number one exporter after taking the top spot from Germany in 2009. China's total 2009 were US\$1.2 trillion, compared to Germany's US \$1.17 trillion (816 billion euros) (China's customs office, the Federation of German..., 2010). About 20\% of China's exports go to the United States (The World Bank, 2011). The U.S. is China's largest trading partner (LaFleur 2010). In 2010, U.S. exports of goods to China jumped 32\%, to US\$92 billion (Your Next Job:..., 2011). 7 of China's top 10 big partners in trade are in Asia continent (LaFleur 2010) Six of the world's largest container ports are in China.(Trading Places...2010). China was the second-largest recipient of Foreign Direct Investment (FDI) in 2009. (United Nations, 2010). China attracted $\$ 105.7$ billion in foreign direct investment in 2010-the first time FDI in China crossed the $\$ 100$ billion mark (China FDI rises strongly..., 2011); (Foreign Direct Investment, 2011).

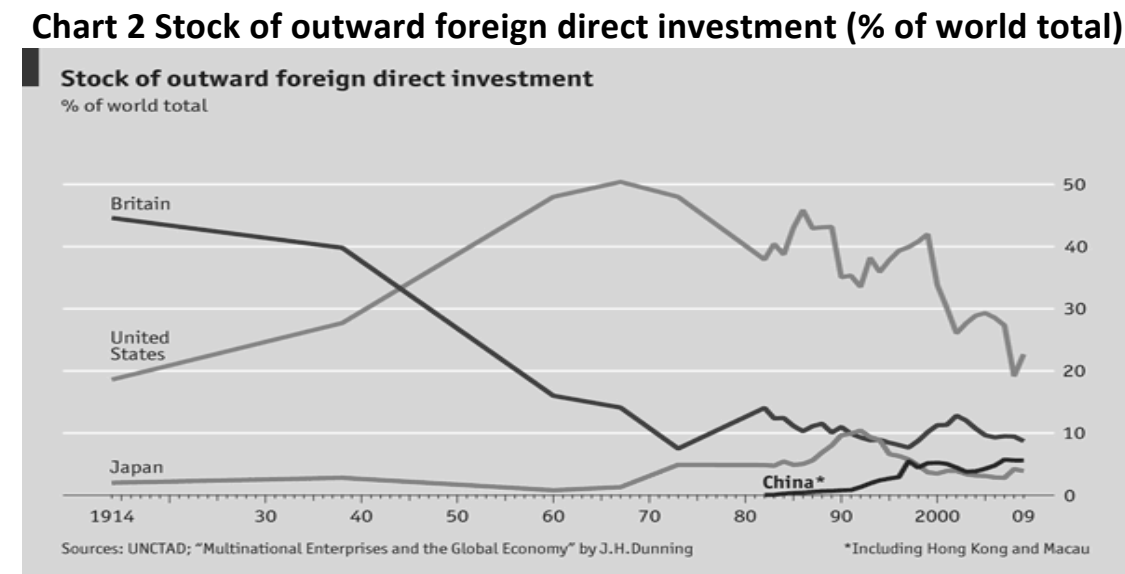

(*Incuding Hong Kong and Macau. Source: UNCTAD, 11.10.2013) 


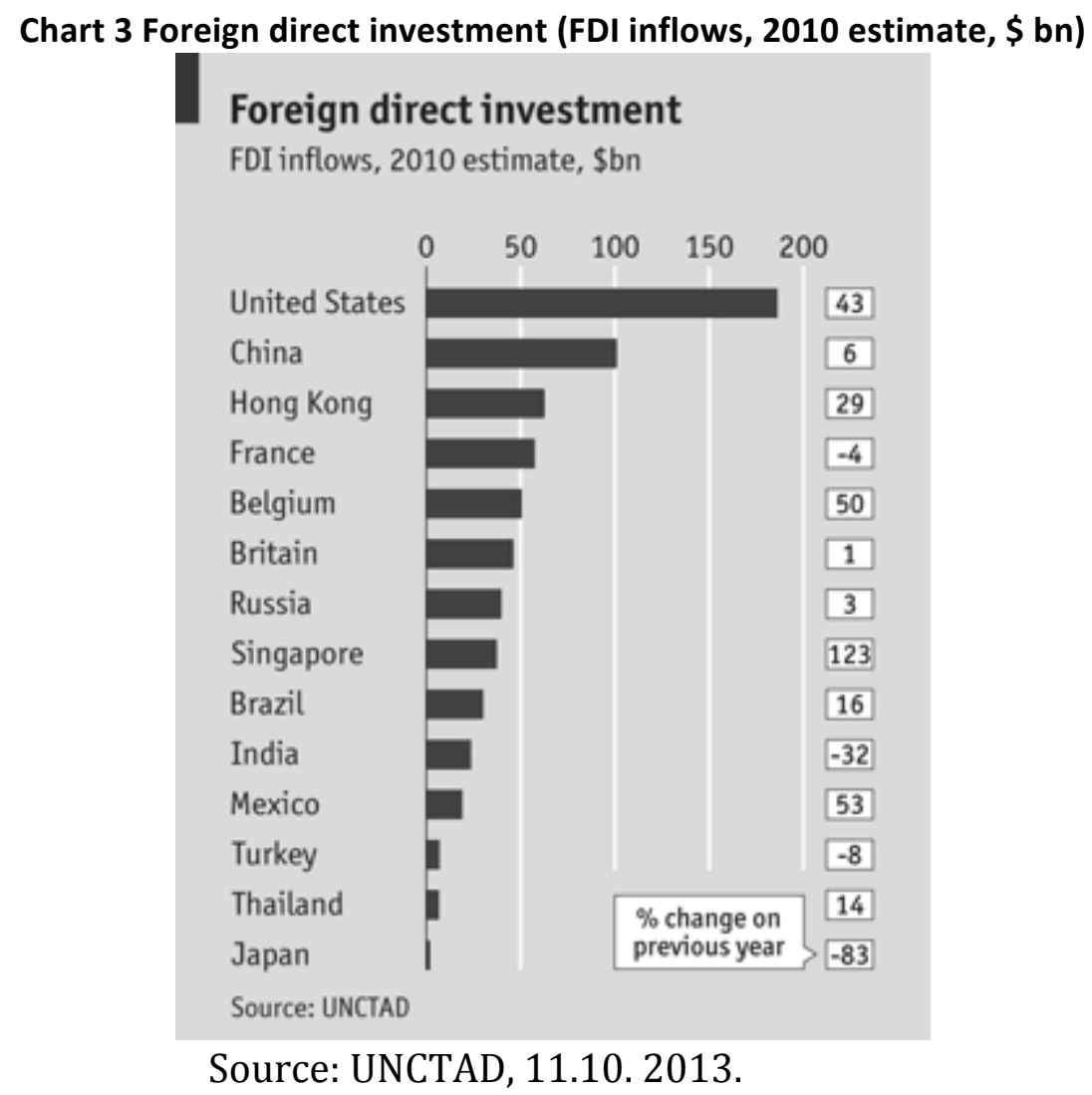

China's weak currency - which is good for Chinese exports-also makes the yuan (RMB) one of the most undervalued currencies in the so-called "Big Mac index", a measure of purchasingpower parity. While a Big Mac averages US\$3.71 in the U.S we can buy one in China for only 14.5 yuan (RMB) (US\$2.18) in Beijing and Shenzhen on average (Bun Fight, 2010).

China is poised to make its money a global currency, which "could strengthen China's influence in overseas financial markets and begin to erode the dollar's dominance." China's has over US $\$ 1$ trillion in foreign exchange reserves (exceeding Japan's), and continue to grow around $\$ 200$ billion each year (The World Bank 2011). China's foreign-exchange reserves hit record highs on Q4 2010 to reach US $\$ 2.85$ trillion. The $\$ 199$ billion gain was the largest quarterly increase since Bloomberg data began in 1996 (China's Currency Reserves Rise..., 2011). China owns over $25 \%$ of U.S. Treasury Bonds and is the largest creditor in the world (Rediff Business, 2010).China is also the U.S.A.'s largest creditor, holding more than $\$ 900$ billion worth of

U.S. This value indicated Treasury bonds of the USA in October 2010. The second and threeted creditors are Japan and the U.K (Factbox: China leads..., 2011).

China's emerging market stocks are predicted to quintuple in the next two decades-reaching a market value of around $\$ 80$ trillion by 2030 (Sachs, Moe 2010). The Shanghai Stock Exchange was the fifth largest stock market in the world in December 2010 (market capitalization of US $\$ 2.7$ trillion) (List of stock..., 2013). Eight of the ten largest stocks on the Shanghai Stock Exchange are state-controlled enterprises. 


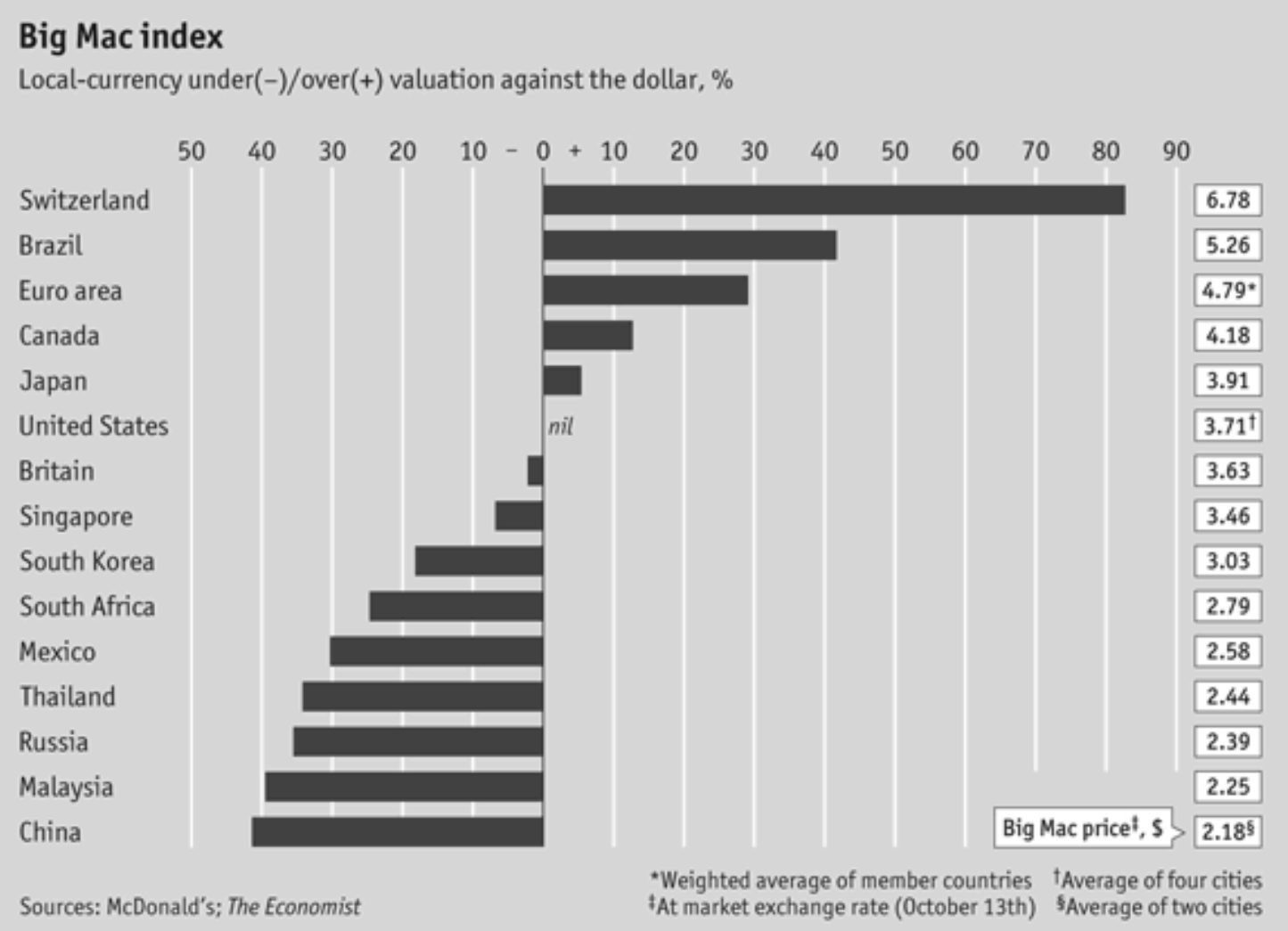

Source, McDonald's; The Economist, http://www.china-mike.com/facts-about-china/economyinvestment-business-statistics/ 11.10. 2013.

\section{THE INCREASE OF CHINA ROLE IN THE EUROPEAN UNION EXTRA TRADE}

The access of China to WTO was a historical decision, the evidence of evolution which was taking place within that organisation, giving it a more universal, global form. This means also that it expands on a huge market which can open itself up for foreign competition. Consequently, the transnational corporations, from semiconductors to the internet and passenger cars, will press strongly for the door to China to be opened wider. However, there are many problems to be solved in China itself. The country is undergoing the transformation towards the market economy. Gaining the economic balance is still very difficult. The United States and Great Britain are helping to introduce there so-called "market shock". The war against terrorism exerts a tremendous pressure on the world economy. Among other things, it accelerated the access of China to WTO, making this country part of the present world. It becomes obvious that also China has joined that war.

In China one has to do with the same accumulation and a similar type support for industry to that which can be observed in case of her production rivals from Latin America and South-East Asia. Such cities as Beijing or Huangho manufacture and supply, on a global scale, electronic equipment of the world quality. Car manufacturing also develops very fast. The enterprises with mixed capital, of the joint venture type, produce in a particularly intensive way. Such Shanghai firms as Shanghai Automotive Industry Corp., which has a capital co-operation with Volkswagen and General Motors Corp., and Tianjin Automotive, co-operating with Toyota Motor Corp., belong to that group of enterprises.

The Chinese successes lead to a more expensive labour force, and consequently different firms from the developing countries start offering a cheaper labour force, although not in large quantities so far. Even India, where wages are the lowest in the whole world, is not able to 
compete with the productivity of China in the area of low technology industrial goods. Hence, the shops of Bombay and Calcutta are filled with Chinese products.

In general opinion, as far as China is concerned, WTO is both a challenge and a chance. However, in case of agriculture, it is easy to see the challenge, while the chances are rather difficult to spot. The reason lies in the fact that the area of the Chinese farms most often does not exceed half a hectare, which means they are too small when compared with the American agricultural giants. Nevertheless, during the last two decades the Chinese laid strong foundations for reforms. A long-termed stability of that country depends also on the fast economic growth, which is possible only when the foreigners become convinced that China is a partner able to play global roles. Both the world and China should be properly prepared for this.

China supports globalisation, declaring that it is the most efficient way of fighting poverty. This country wants to be a part of a global world and it is aware that it must observe its laws. Currently, China is the largest destination for foreign investment (Reuvid, 2008). Due to China's access to WTO, her share in the world trade will increase from 3\% to 7\% (in 1986 it was only $0,7 \%$ ). The results of the transition provide compelling evidence of the efficiency of market incentives. Other factors that have contributed to China's ascendancy to a world economic power include privatizing much of its industry, formation of the Chinese Stock Exchange, passage of the Company Law (1993) and a multitude of corporate governance principles to protect shareholders and provide a framework of shifting from state to private ownership of capital (Doherty and Lu, 2013). It is being estimated that by the year 2020 China will take the first position among the world powers.

Further trade liberalisation and improved framework policies would increase trade and promote growth. It must be emphasized that openess to trade is associated with higher incomes and growth and there are the need for new approaches to trade cooperation in light of the forces that are currently re-shaping international business. The key of trade developments within the broader socio-economic context is especially the rise of global supply chains, the general shift of trade power away from the West towards Asia.

A major factor, was the even more remarkable transformation of China, as market reforms opened up its economy to foreign trade and investment, and unleashed an unprecedented growth dynamic that has continued, with only minor slowdowns. In the new circumstances for the development of the global economy and the global trade, People Republic of China seems to be a production superpower, able to change the world trade. In many areas it possesses comparative advantages. The question raised is whether the West will see China's rise as an opportunity for cooperation or for conflict. Economic growth is generally more preferable in China to military and extensive expansion. With new investments, a country can transform its position through industrial expansion at home and sustain it through international trade. China is especially sensitive to the advantages of intensive growth and will not wish to disrupt essential economic arrangements that have been crucial to her success.

Estimates by R.J. Tammen at al.(2000) anticipate that China will overtake the United States in mid-century (Tammen, Kugler, Lemke, Stam, Abdollahian, Al-Sharabati, Efird, and Organski 2000). Thus American dominance should endure until mid-century. Afterwards, Asian demands for modification to the international system will likely increase, and unless resolved, will be increasingly likely to be imposed by force. The question raised by this empirically grounded extrapolation is whether the West will see China's rise as an opportunity for 
cooperation (as former European enemies did when responding to the post-World War II resurgence of Germany by creating the EU) or for conflict (Kugler, 2006, p.39).

Table 2 the global balance of economic powers in 2010 versus 2020

\begin{tabular}{|c|c|c|c|c|}
\hline Rank & Country - 2010 & GDP (U\$ million) & Country - 2020 & GDP (U\$ million) \\
\hline 1 & USA & $14,802,081$ & China & $28,124,970$ \\
\hline 2 & China & $9,711,244$ & USA & $22,644,910$ \\
\hline 3 & Japan & $4,267,492$ & India & $10,225,943$ \\
\hline 4 & India & $3,912,911$ & Japan & $6,196,979$ \\
\hline 5 & Germany & $2,861,117$ & Russia & $4,326,987$ \\
\hline 6 & Russia & $2,221,755$ & Germany & $3,981,033$ \\
\hline 7 & United Kingdom & $2,183,277$ & Brazil & $3,868,813$ \\
\hline 8 & France & $2,154,399$ & United Kingdom & $3,360,442$ \\
\hline 9 & Brazil & $2,138,888$ & France & $3,214,921$ \\
\hline 10 & Italy & $1,767,120$ & Mexico & $2,838,722$ \\
\hline
\end{tabular}

Source: Facts about China: ECONOMY \& GDP 2011-2012, http://www.china-mike.com/factsabout-china/economy-investment-business-statistics /

Economic growth is generally more preferable in China to military and extensive expansion. With new investments, a country can transform its position through industrial expansion at home and sustain it through international trade. Since World War II, a number of economies have adopted peaceful development principle, including Germany, Japan, China and other East Asian Nations (Rosecrance, 2006, p.33)..

It is important to underline that China will enter a world market in which many of the spoils have already been appriopriated. China will be studded with western firms contributing high technology to Chinese development. Aside from textiles, however, it is not clear how many purely Chinese industries will attain economies of scale.

It must be emphasized that, even high developed countries economically will be at least partly dependent on industries headquartered somewhere else. Even today, America does not represent the attainment of unipolarity in economics, whatever its military might. It is dependent upon money market and foreign direct investment from China, Japan, and Europe. Economic concentration today has three or four different options. The same will be true in the future. Decreasing cost (increasing returns) industries will be located in different zones and no one Great Power will monopolize them all. Europe will boast the London-Frankfurt and ZurichMilan way. USA has high competitive champions in two zones-Boston to North Carolina and San Diego to Seattle. China will have industrial or software concentrations in north China, Fujian, and Guangdong terminating in the Pearl River Delta. In this place it is important to underline that no country, powerful in terms of GDP, will incorporate all worldwide industrial or service potential. It is even possible that the defense industry on an international basis is one of increasing returns to scale. Under the circumstances, there will be overlapping zones of economic competency among high developed coutries.

The assumed result of one Great Power hegemony replacing another and a shift between unipolarities will not be obtained in the next few decades. Thus, even very powerful countries militarily will find themselves needing the products and markets of countries (and corporations) located somewhere else. In theory, a very strong power militarily might be able to expand to take over the industries on which it indicat dependence. Again, cost-benefit reasons would cut against any attempt at conquest - opennes would provide acces to such industries much more efficiently (Rosecrance, 2006, p.35). 
It cannot be sure that the more full-throated globalization of the present and future will remedy the difficulty. History shows that states sometimes engage in war for insufficient reasons. Short-term motives take procedence over long-term maximization. But they are not likely to do so between the United States, European Union and China, both long-term maximizers. China is especially sensitive to the advantages of intensive growth and will not wish to disrupt essential economic arrangements that have been crucial to her success.

In addition, should she decide otherwise, there are neighboring power that would present barriers to extensive expansion? Japan, a unfied Korea, India, and Russia.. Japan, perhaps, has traditionally underused her power, but this is not true of Russia or India. A unified Korea will represent another position in relation to China. It must be emphasized that economic ties with these counties will be preferable to military expansion against them. And the presence of the United States and its military bases will occasion additional hesitation. No one can be certain that relations among Great Powers will be peaceful ones over the long term. But the current relationships make that prospect much more likely than it has been in the past (Rosecrance, 2006, p.35).

The integration of China and India into the world trade system may have increase aggregate welfare in the rest of the world by $0,4 \%$ but factor incomes in individual sectors may fall or rise by more than 5\% (Braconier, Nicoletti, Westmore 2014:36). Dealing with relative wage pressures and needs for structural adjustment due to rising trade integration will thus be important. The benefits from trade libaralization are transmited through several channels like shifting production from low to high locations, relocation of factors of production towards sectors and firms with high productivity and rising incomes due to an increase in market size that supports more specialisation, faster technology diffusion and stronger incentives to invest in "non-rival" assets (Braconier, Nicoletti, Westmore 2014:36). The former two effects include mostly static from international trade in goods, services and factors of production, while the latter entails dynamic growth effects. Significant static and dynamic efficiency gains especially for South countries - could be reaped through further multilateral trade liberalization while global welfare gains from regional agreements are much more limited due to trade diversion (Johnson and Olaberia 2014).While fostering multilateral trade liberalisation has proved difficult in the recent past and regional arrangements have been frequent, the former should remain priority due these larger benefits and despite the practical challenges of seeing through such reforms in a multipolar world (Puślecki 2008). This results are based on the "Partial multilateral" trade liberalization scenario based on multilateral cuts in tariffs (50\%) and transaction cost (25\%) realative to basline (Johnson and Olaberia 2014).

It is important to underline that also fiscal consolidation will require major efforts in several countries. Fiscal pressures will build up in reverce areas over coming decades unless extensive fiscal reforms are pursued. Asia growth could be curbed further by damages from environmental degradation due inter alia to climate change, wich are likely to affect these countries earlier than expected. By 2060, environmental damages in South and South Asia may lower GDP by more than 5\% compared to the central scenario (Braconier, Nicoletti, Westmore 2014:36).

China's growth is good for the world economy and for the European Union with significant terms of trade gains being experienced in its trading partners, reduction in poverty and increases in living standards. Chinese economic growth has been good for Chinese with massive reductions in poverty and rising living standards. Moreover, China is now a very large regional power and the preceding discussion has provided evidence that it is having a very 
large growth effect on its neighboring trade partners. If China continues its path of stable growth there is every reason to export continued and expanded benefits for its trade partners.

Rapid economic growth appears to have spread from China and others East/South Asia countries to Latin America and now Africa, and, while much of the old capitalist heardland is mired in economic stagnation and fiscal crisis, the 'emerging economies' face an investment glut. Curerent trends in world economy and global politics provide evidence that the Global South has now arrived at 'normal' capitalism at last, bringing with it new patterns of uneven development, inequality and injustice (Radice 2015:206). Its newly confident elites, now fully engaged in global circuits of trade, investment and finance, and in global governance too, appear to have left behind their previous role. It is clear that the Global South, or in elite-speak the 'emerging economies', has sufferd less and recoverd more quickly that the advanced capitalist heartland. In addition, in 2011 it now seems that the patterns of political impact - not in the sense of immediate crisis measures but of long-term "tectonic" shifs - may be equally significant and unexpected (Radice 2015:206). While political elites in the USA, European Union and Japan struggle to find pats of recovery that are acceptable to their confused and divided electorates, remarkable changes of various kinds are observable across Global South and also in China..

\section{EUROPEAN UNION AND CHINA IN THE LIGHT OF THE GLOBAL COMPETITIVENESS STRATEGY THE EUROPE 2020}

China may continue to specialise in electronics and increasingly in services, while maunfacturing may continue in the framework of the relations with the OECD and also with the European Union countries. With or without further trade agreements, services will be more traded and trade policies will have to adjust to changes in the organisation of global value change (Braconier, Nicoletti, Westmore 2014:17). It must be emphasized that the EU has a strong record of international co-operation and of providing development support and assistance to many parts of the world. This includes promotion of human rights in all external actions, addressing inequalities and advocating gender equality. However, development policy must also be continuously adapted to the evolving needs of partner countries to best deliver on EU commitments. With 2015 being the European Year for Development, the EU will continue its work on the post 2015 Sustainable Development Goals and will launch reflections on its future relations with China and others developing countries (post- Cotonou) (COM 910 final 2014).

The budgetary and economic policies with the Stability and Growth Pact and the Europe 2020 strategy are the basis for building a common understanding about the priorities for action at the national and EU level as the EU seeks to return to a path of sustainable growth and job creation.The key driver of the problems is Europe's structural innovation gap: compared to its competitors also like China. Europe's patenting performance is weak and it lags behind in developing new products, new processes and new services. To boost productivity and growth, it is critically important to generate breakthrough technologies and translate them into new products, processes and services. Europe has taken an early technological lead in many key technology areas, but in the face of growing competition its advantage is tenuous, and has not translated into an innovative and competitive lead. A timely and targeted European policy is needed for bridging the "valley of death" if Europe is to remain competitive (SEC 1428 final 2011).

This key driver is underpinned by the following structural problem:

- Insufficient contribution of research and innovation to tackling societal challenges 
- Insufficient technological leadership and innovation capability of firms

- The need to strengthen the science base

- Insufficient cross-border coordination

The EU recognizes the urgency of the situation, and is responding with new policy strategies. It is important to underline that the Innovation Union is one of the seven flagship initiatives of the Europe 2020 strategy for a smart, sustainable and inclusive economy.

Innovation Union is the European Union strategy to create an innovation-friendly environment that makes it easier for great ideas to be turned into products and services that will bring economy growth and jobs (Chart 5, Chart 6).

Chart 5 GDP trends in the EU: levels and rates

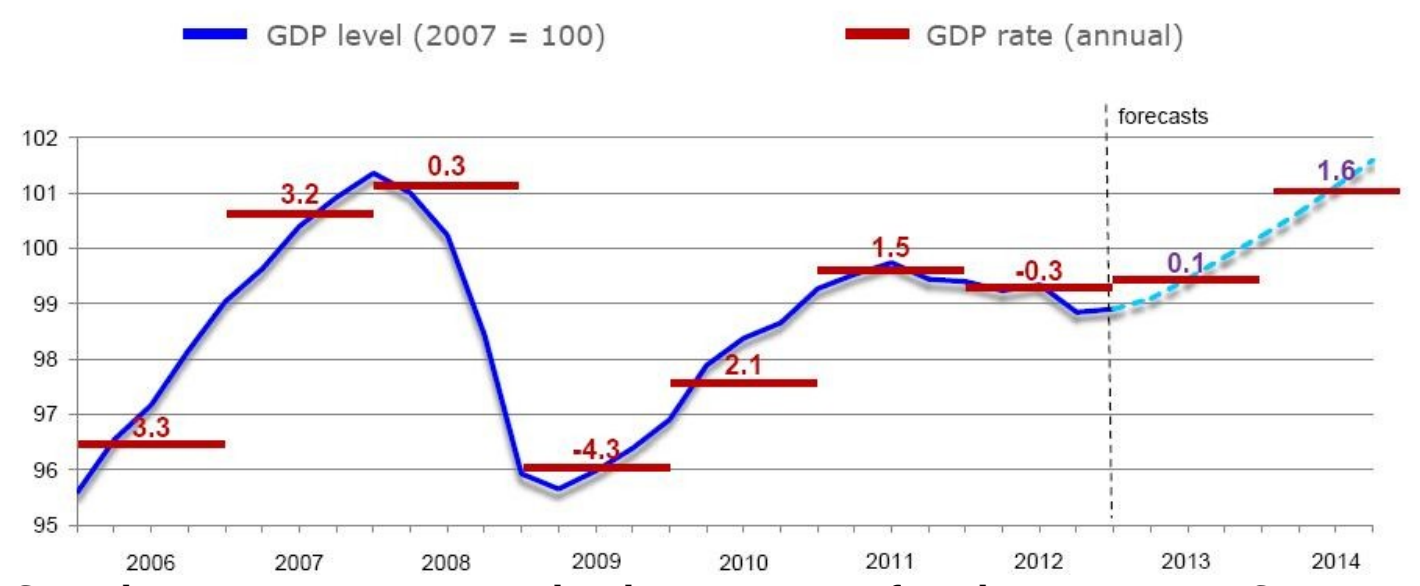

Source: Growth, competitiveness and jobs priorities for the European Semester 2013. Presentation of J.M. Barroso, President of the European Commission to the European Council of 14-15 March 2013, http://europa. Eu/news/pdf/sg. 2013-00286-01-04-eu. Tra-00. Pdf. Access, 24.01.2014.

The Europe 2020 strategy is the basis for building a common understanding about the priorities for action at the national and EU level as the EU seeks to return to a path of sustainable growth and job creation.

Chart 6 Number of people employed in the EU (in million)

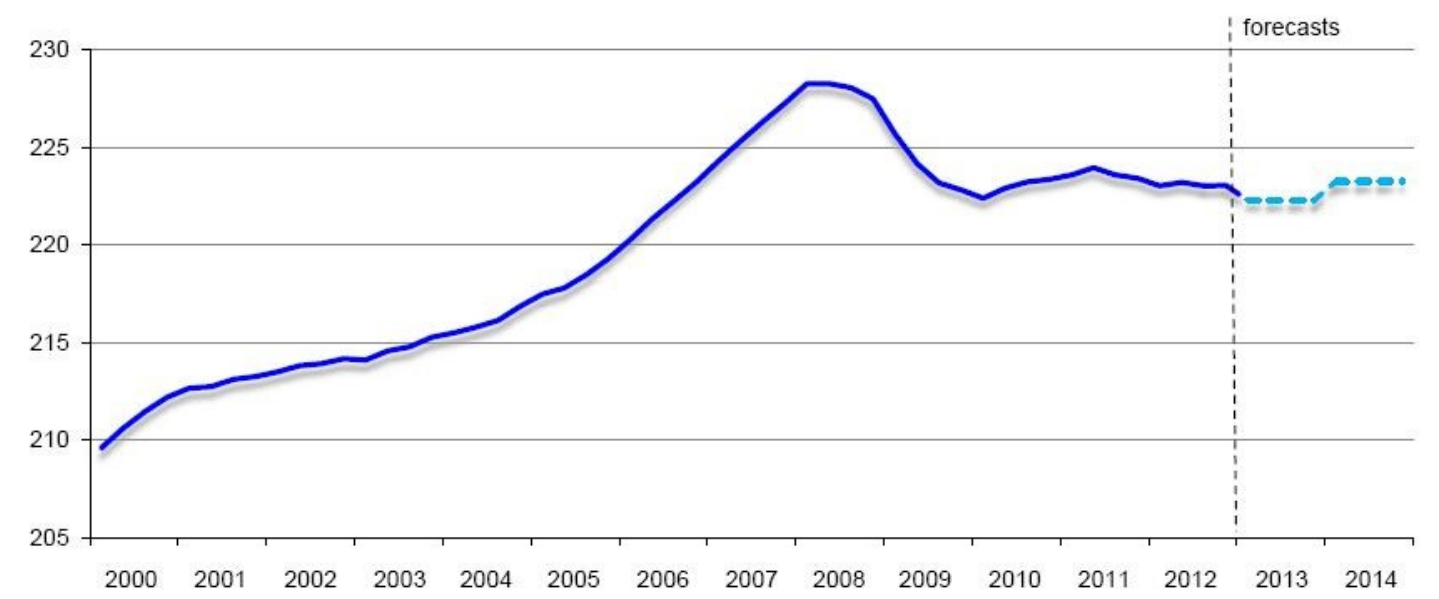

Source: Growth, competitiveness and jobs priorities for the European Semester 2013. Presentation of J.M. Barroso, President of the European Commission to the European Council of 14-15 March 2013, http://europa. Eu/news/pdf/sg. 2013-00286-01-04-eu. Tra-00. Pdf. Access, 24.01.2014. 
The deleveraging and adjustment process is inevitable and the main task of policy makers is to manage it and alleviate the associated economic and social consequences. Fiscal adjustment has to continue along the path of a differentiated growth-friendly consolidation strategy in view of the high debt levels and long-term challenges to public finances.

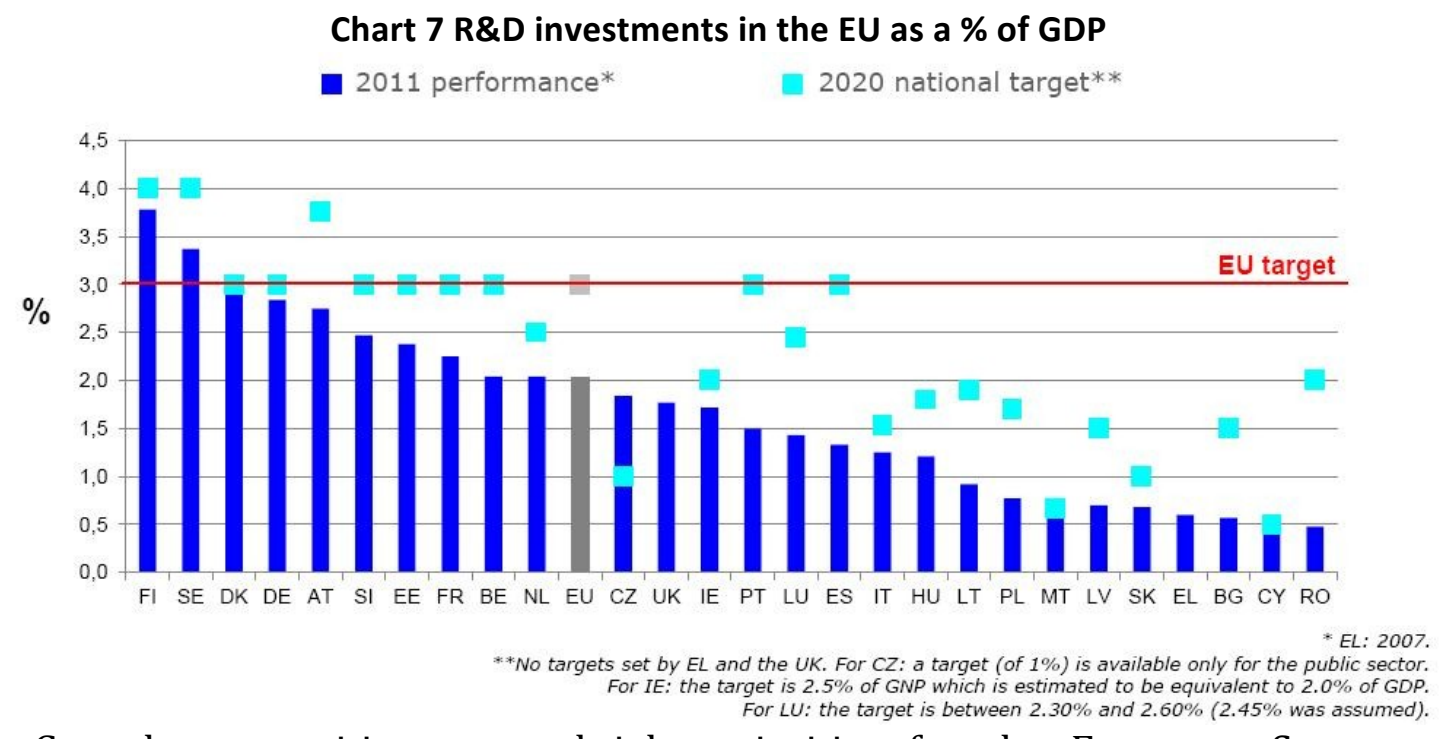

Source: Growth, competitiveness and jobs priorities for the European Semester 2013. Presentation of J.M. Barroso, President of the European Commission to the European Council of 14-15 March 2013, http://europa. Eu/news/pdf/sg. 2013-00286-01-04-eu. Tra-00. Pdf. Access, 24.01.2014.

It must be emphasized that Horizon 2020 is the financial instrument implementing the Innovation Union a Europe 2020 flagship initiative aimed at securing Europe's global competitiveness. Running from 2014 to 2020 with a budget of just over $€ 70$ billion, the EU's new programme for research and innovation is part of the drive to create new growth and jobs in Europe Horizon 2020 provides major simplification through a single set of rules also to the China.

It is important underline that the Europeans have been disapointed by their own inability to guid the PRChina toward "effective multilateralism" and frustrated in their support of internal political change. The Chinese, for their part, have interpreted the "strategic partnership" as an opportunity not only to play Europe off against the United States but also to receive official status as a market economy from the EU Commission in order to reduce the risk of trade sanctions ( Heilman and Schmidt 2014: 181).

\section{CONCLUSIONS}

The trade policy plays a key role in the maintenance of both economic and political liberalization. The prominence of rent seeking in a country can have far-reaching implication for its economic development. Especially in transitional countries like China, rent seeking takes scarce resource out of productive areas in the economy, using them to promote and/or perpetuate further rents. However it should be stressed that free trade in itself is not responsible for economic growth, but more significant are the determining macroeconomic stability and increasing investment

International cooperation of the European Union also with China will be an important crosscutting priority of the Horizon 2020. In addition to Horizon 2020 being fully open to international participation, targeted actions with key partner countries also with China and 
regions will focus on the EU's strategic priorities. Through a new strategy, a strategic and coherent approach to international cooperation also with China will be ensured across Horizon 2020. The intensity of trade and financial links with China differs among individual EU countries. The United Kingdom, Finland and the Netherland's have extensive links with China, while many other EU countries have quite modest economic ties among which Germany, as Europe's largest economy, will play a prominent role.

\section{References}

Braconier H., Nicoletti G., Westmore B., (2014), Policy Challenges for the Next 50 Years, OECD Economic Policy Paper, July 2014, No 9, Authorised for publication by Jean-Luc Schneidr, Deputy Director, Policy Studies Branch, Economic Department OECD, Better Policies for Better Lives, OECD Economic Policy Papers No 9

Chen Xinen (2009). Review of China's agricultural and rural development: Policy changes and current issues, "China Agricultural Economic Review", Vol. 1, No. 2, pp. 121-135

China FDI rises strongly in January, outlook bright, (2011): "Reuters" Feb. 17,

China is richer, but most Chinese are still poor, (2011): “Fortune”, Feb. 17.

China Passes Japan as Second-Largest Economy (2010): “New York Times”, August 15.

China Statistical Yearbook (2010).

China Surges in Americans' Views of Top World Economy, (2011):"Gallup's annual WorldAffairs survey", Feb.,

http://www.china-mike.com/facts-about-china/economy-investment-business-statistics/ 11.10. 2013

China vows tougher punishments for copyright piracy, (2011): “Reuters”, January, 10,

China's Currency Reserves Rise to Record, Domestic Lending Exceeds Target, (2011):

“Bloomberg", Jan. 11.

China's customs office, the Federation of German Wholesale and Foreign Trade, (2010)

New York Times, January 10

CIA-The World Factbook, China (2006), www.cia.gov/cia/

CIA World Fact Book, (2011)

$\operatorname{COM(2014)~} 910$ final, Communication from the Commission to the European Parliament, the Council, the European Economic and Social Commitee and the Committee ot the Regions, Commission Work Programme 2015 A New Start, Strasbourg, 16.12.2014

Copland, B.R. and Taylor M. S. (1995): Trade and Transboundary Pollution, “American Economic Review”, 85 (4), pp. 713-737.

Corden W.M. (1996): The Environment and Trade Policy, In: Corden W. M. (Eds), Trade Policy and Economic Welfare, Oxford: Clarendon Press.

Doherty, A. N., Lu, F.V., (2013); China: Spectacular Growth and Inequality, “Journal of Business and Economics", March, Volume 4, No. 3, pp. 195-201

Facts about China: Economy \& GDP 2011-2012, http://www.china-mike.com/facts-about-china/economy-investmentbusiness-statistics/ (Access 11.10. 2013).

In China, Even Crooks Get ripped off" (2011) China facts: Weird \& Oddbal

In China, Tentative Steps Toward Global Currency, (2011), "New York Times”, Feb. 10

Gallup's annual World Affairs survey, “China Surges in Americans' Views of Top World Economy” Feb. (2011\}

Goldman Sachs Global ECS Research, Dec. (2010) 
Growth, competitiveness and jobs priorities for the European Semester 2013. Presentation of J.M. Barroso, President of the European Commission to the European Council of 14-15 March 2013, http://europa. Eu/news/pdf/sg. 2013-0028601-04-eu. Tra-00. Pdf. Access, 24.01.2014.

Heilmann S. and Schmidt D.H. (2014): China's Foreign Political and Economic Relations. An Unconventional Global Power, Rowman\&Littlefield, Lanham, Maryland, USA

Jian T., Sachs J. D. and Warner A. M. (1996). Trends in regional inequality in China, "China Economic Review", Vol. 7, No. 1, pp. 1-21.

Johnsson A., and E. Olaberria (2014). Long-term Patterns of Specialisation and Trade, OECD Economic Department Working Papers forthcoming OECD Publishing Paris.

Kawase, T.(2005): WTO Safeguard Agreement,In: “RIETI Report" No. 045 (27 July) (2004a). Available at http://www.rieti.go.jp. (Accessed November 13).

Kawase, T.(2006): Safeguard Under the WTO Regime Realities and Problems.In: "Research \& Review", (2004b). Available at http://www.rieti.go.jp. (Accessed January 8).

Kugler, J., (2006): The Asian Ascent: Opportunity for Peace or Precondition for War? “International Studies Perspectives, A Journal of the International Studies Association", Volume 7, Number 1, February.

LaFleur, R. (2010), China: Asia in Focus,

http://www.china-mike.com/facts-about-china/economy-investment-business-statistics/ Access 11.10. 2013

McDonald's; The Economist, http://www.china-mike.com/facts-about-china/economy-investment-business-statistics/ Access 11.10. 2013.

Puślecki Z.W.,(2008): Mercantilist Tendencies in Contemporary Foreign Trade Policy, "Journal of Global Change and Governance", Division of Global Affairs (DGA), Rutgers University, New Jersey, USA, Volume I, Number 4, Autumn

Radice, H. (2015). Global Capitalism. Selected essays, Routledge, Tylor \& Francis Group, London and New York

"Rediff Business online", (2010), November,

http://www.china-mike.com/facts-about-china/economy-investment-business-statistics/ 11.10. 2013

Reuvid J. (2008). Business Insights—China, Kogan Page, London and Philadelphia

Rosecrance, R., (2006): Power and International Relations: The Rise of China and Its Effects, "Internationl Studies Perspectives, A Journal of the International Studies Association”, Volume 7, Number 1, February.

Sachs J. and Warner A. (1995). Economic reform and the prices of global integration, "Brooking Papers on Economic Activity", Vol. 1, pp. 1-118

SEC, (2011). 1428 final Volume 1, Commission Staff Working Paper Executive Summary of the Impact Assessment Accompanying the Communication from the Commission "Horizon 2020 - The Framework Programme for Research and Innovation", Brussels, 30.11.2011

Tammen, R.J, J. Kugler, J., Lemke, D., Stam, A., Abdollahian, M., Al-Sharabati, C., Efird, B., and Organski, A.F.K., (2000): Power Transition, New York: Chatham House.

The World Bank, (2011).

Top 10 largest economies in 2020, (2010): “Euromonitor International”, July 7. http://www.china-mike.com/factsabout-china/economy-investment-business-statistics/ Access 11.10. 2013

World Bank China (2009), Research Working Paper No. 9 